\title{
The Corelation of Exclusive Breastfeeding with Nutritional Status in Babies Age 6-24 Months at the Kedungsari Health Center, Mojokerto Regency
}

\author{
Sukma Sahadewa ${ }^{1 *}$, Nike Salindri ${ }^{1}$, Sandra Miladyna ${ }^{1}$, Siti Hadijah ${ }^{1}$ \\ Fakultas Kedokteran, Universitas Wijaya Kusuma Surabaya ${ }^{1}$ \\ *e-mail: sukmasahadewa83@gmail.com
}

\begin{abstract}
The objectives of this research is to find out the prevalence of exclusive breastfeeding, nutritional status, and the correlation between of breastfeeding and nutritional status in babies aged 6 to 24 months at the Kedungsari Public Health Center in Mojokerto Regency. This study used 50 babies aged 6-24 months from the Kedungsari Health Center as samples. This study applied a cross-sectional study design. The data was collected by gathering primary data via questionnaires and secondary data from the Kedungsari Health Center. The majority of the children in this research, aged 6-24 months, had been exclusively breastfed (58\%). The majority of the children in this research, aged 6 to 24 months, showed normal nutritional status (74\%). Furthermore, in the Kedungsari Health Center in Mojokerto Regency, there is a correlation between of breastfeeding and nutritional health in infants aged 6 to 24 months. This study's findings provide up-to-date information on the prevalence of exclusive breastfeeding, nutritional status, and the correlation between exclusive breastfeeding and nutritional status in babies aged 6 to 24 months.
\end{abstract}

Keywords: Exclusive breastfeeding, nutrition, public health.

\section{Korelasi Pemberian Asi Eksklusif terhadap Status Gizi pada Bayi Umur 6-24 Bulan di Puskesmas Kedungsari, Kabupaten Mojokerto}

\begin{abstract}
Abstrak
Studi ini bertujuan untuk mengetahui prevalensi asi eksklusif, status gizi dan korelasi pemberian ASI eksklusif dengan status gizi pada bayi umur 6-24 bulan di Puskesmas Kedungsari Kabupaten Mojokerto. Sebanyak 50 bayi berusia 6-24 bulan di Puskesmas Kedungsari dengan digunakan sebagai sampel dalam penelitian ini. Desain studi yang digunakan dalam penelitian ini adalah kajian cross sectional. Data diperoleh dengan cara pengumpulan data primer melalui kuisioner dan data sekunder dari Puskesmas Kedungsari. Sebagian besar anak usia $6-24$ bulan dalam penelitian ini pernah mendapat ASI eksklusif (58\%). Mayoritas anak usia 6 - 24 bulan dalam penelitian ini memiliki status gizi kategori normal (74\%). Selain itu, terdapat hubungan antara hubungan antara pemberian ASI eksklusif dengan status gizi pada anak umur 6-24 bulan di Puskesmas Kedungsari Kabupaten Mojokerto. Hasil penelitian ini memberikan informasi terkini terhadap kejadian asi eksklusif, status gizi dan korelase pemberian asi eksklusif dengan status gizi pada bayi umur 6-24 bulan.
\end{abstract}

Kata Kunci: ASI ekslusif, gizi, kesehatan masyarakat. 
The Corelation of Exclusive Breastfeeding with Nutritional Status in Babies Age 6-24 Months... Sukma Sahadewa, Nike Salindri, Sandra Miladyna, Siti Hadijah

\section{INTRODUCTION}

Giving breast milk without other food or drink to infants at 0-6 months is called exclusive breastfeeding (Prasetyono, 2012). Babies are exclusively breastfed for six months after birth, without the addition or replacement of any other food or drink (except drugs, vitamins, and minerals) (Kemenkes RI, 2016). The World Health Organization (WHO) advises that newborns breastfeed exclusively until the age of six months, followed by supplementary meals until the baby is two years old or older (Marnoto, 2010). Breastfeeding exclusively benefits children's growth, development, and endurance substantially. Children that are exclusively breastfed will grow and develop to their full potential and not get sick quickly. Exclusive breastfeeding can reduce mortality due to infection by $88 \%$ in infants less than three months old. Exclusive breastfeeding also reduces the risk of obesity and chronic disease (Kemenkes RI, 2016).

The problem of under-five nutrition that Indonesia must face is the problem of undernutrition and overnutrition. The issue of malnutrition is caused by the consumption of nutrients that do not meet their needs at a specific time. As a result, Malnutrition has serious consequences, such as stunted physical growth and suboptimal development and cognition.
Another consequence is decreased productivity and decreased body resistance to diseases that can increase the risk of illness and death (Waryana, 2010).

In the last five years, the achievement of exclusive breastfeeding has not changed much, even though the government's target for exclusive breastfeeding is $60 \%$. The number of infants receiving exclusive breastfeeding has only reached $15.3 \%$ (Riskesdas, 2010). So far, there is an assumption in the community that poor households only experience cases of malnutrition that mostly affect children under five in this country. However, poverty is not the only cause of the prevalence of malnutrition. There are still many other factors that trigger, including low levels of education and cultural problems (Indriyani, 2013). Poverty, a scarcity of food, inadequate environmental hygiene, and a general lack of knowledge about nutrition and health all contribute to malnutrition (Waryana, 2010).

There has never been any research on the correlation between of exclusive breastfeeding and the prevalence of malnutrition in children aged 6-24 months. As a result, the objective of this research is to ascertain the prevalence of exclusive breastfeeding, nutritional status, and the correlation between exclusive breastfeeding and nutritional status in 
babies aged 6 to 24 months at the Kedungsari Health Center in Mojokerto Regency. This data can provide breastfeeding mothers and health experts with a preventive link between of breastfeeding and the occurrence of underweight status.

\section{MATERIALS AND METHODS}

\section{Design Study}

The study's design is cross-sectional, which aims to determine whether there is an correlation of exclusive breastfeeding on the incidence of malnutrition in children aged 6-24 months at the Kedungsari Health Center. In this study, we will examine the relationship between poor nutritional status and exclusive breastfeeding.

\section{Population and Sample}

The Slovin technique was used to calculate the sample size (Lutfy, 2015; Tarigan, 2013). The population in this study were infants aged 6-24 months at the Kedungsari Health Center with a sample size of 50 respondents. The characteristics of the sample used were babies at the Kedungsari Health Center, aged 6-24 months who did not have a tongue tie disorder, did not have congenital abnormalities at birth and were recorded in the Kedungsari Health Center medical record from May to July 2020. Incomplete or illegible medical records will not be sampled.

\section{Secondary Data Collection}

Data has been collected by gathering secondary data, the results of which are received indirectly from the source in question. The examination in this study was conducted by measuring body weight, body length, upper arm circumference, and head circumference, the results of which would be adjusted to the Healthy Towards Card (KMS). Data collection procedures in this study include:

a. Ask for permission from the patient's mother first whether she is willing to be a respondent in this study. If she is ready, an explanation is given to the patient's mother of how the examination procedure is.

b. If the patient's mother is willing, the patient is allowed to fill out a questionnaire first regarding exclusive breastfeeding

c. Preparation of tools used to measure the patient's body weight (BB), upper arm circumference (LLA), head circumference (LK)

d. The patient is laid down then measurements are taken accompanied by the patient's mother

e. Data writing and adapted to KMS charts 
The Corelation of Exclusive Breastfeeding with Nutritional Status in Babies Age 6-24 Months... Sukma Sahadewa, Nike Salindri, Sandra Miladyna, Siti Hadijah

\section{Questionnaire}

Data collection was carried out on babies aged 6-24 months at the Kedungsari Health Center. Mothers of patients whose children will be measured are asked to fill out the questionnaire that has been provided. After obtaining informed consent, measurements were carried out on the respondents using measuring devices.

\section{Data analysis}

The findings of this study's data were processed using SPSS 25 software. Furthermore, the Chi-square test was used to evaluate the data.

\section{RESULTS}

Exclusive Breastfeeding on Respondents' Infants

A total of 50 respondent infants were analyzed descriptively for exclusive breastfeeding. In this study, $42 \%$ of infants were not exclusively breastfed (Figure 1).

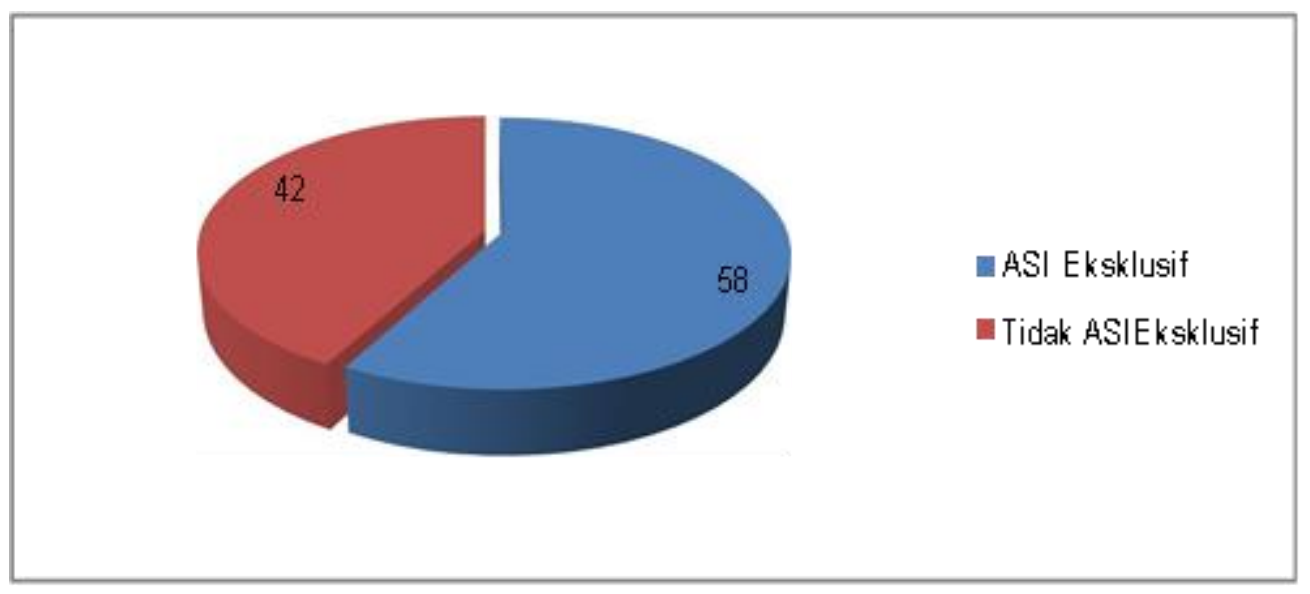

Figure 1. Graph of the proportion of breastfeeding to respondents

\section{Nutritional status}

The nutritional status of the respondent's infants was investigated in this study. This study found that the rate of the respondent's baby at the Kedungsari Health Center who had a weight less than average was $26 \%$. 


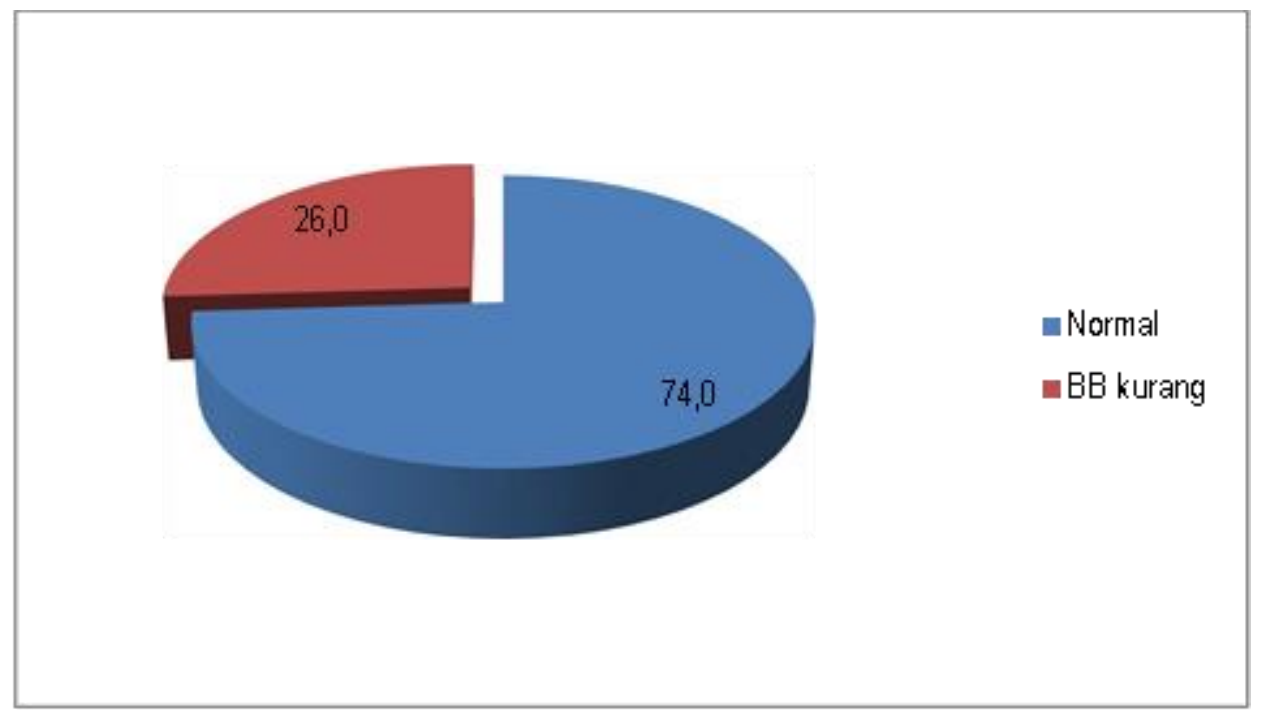

Figure 2. Graph of nutritional status of respondents

Relationship between Nutritional Status of

Children aged 6 - 24 Months with

\section{Breastfeeding}

Based on Table 1, the group of respondents who gave exclusive breastfeeding to their babies was $96.6 \%$ had average weight. Meanwhile, the respondents who did not exclusively breastfeed their babies only had $42.9 \%$ of babies with normal nutritional status. In this study, infants aged 6-24 months were not found in the overweight category. The $p$ value is $0.000(0.05)$ from the findings of the chi-square test, indicating that there is a correlation between of exclusive breastfeeding and the incidence of nutritional status in babies aged 6-24 months at the Kedungsari Health Center in Mojokerto Regency (Table 1).

Table 1. Relationship between children aged 6 to 24 months' nutritional status with breastfeeding

\begin{tabular}{|c|c|c|c|c|}
\hline \multirow{2}{*}{ Breastfeeding } & \multicolumn{2}{|c|}{ Nutritional status } & \multirow{2}{*}{ Total } & p-value \\
\cline { 2 - 3 } & Normal & Less weight & & \multirow{2}{*}{0,000} \\
\hline $\begin{array}{c}\text { Exclusive } \\
\text { breastfeeding }\end{array}$ & $28(96,6 \%)$ & $1(3,4 \%)$ & $21(100 \%)$ & \\
\hline $\begin{array}{c}\text { Non-exclusive } \\
\text { breastfeeding }\end{array}$ & $9(42,9 \%)$ & $12(57,1 \%)$ & & \\
\hline Total & $\mathbf{3 7}(74,0 \%)$ & $\mathbf{1 3}(26,0 \%)$ & $\mathbf{5 0}(100 \%)$ & \\
\hline
\end{tabular}

\section{DISCUSSION}

Breast milk is the best meal for infants aged 0-6 months, with the maximum nutritional content when compared to artificial foods or milk obtained from animals, such as cow's milk or goat's milk (Atika, 2014). Breast milk contains highquality nutrients so that it is helpful for growth and development and contains a composition according to the required needs. Breast milk has an advantage over 
The Corelation of Exclusive Breastfeeding with Nutritional Status in Babies Age 6-24 Months... Sukma Sahadewa, Nike Salindri, Sandra Miladyna, Siti Hadijah

other meals for newborns, such as formula milk, in that the protein level is lower in breast milk than in cow's milk, so it does not stress the kidneys and the kind of protein is simple to digest. In addition, breast milk contains fat in essential amino acids, saturated fatty acids, medium-chain triglycerides, and cholesterol in sufficient quantities for the baby's needs. Breast milk is the primary energy source and the main source of protein, vitamins, and minerals for babies. Due to the high nutritional content of breast milk, babies who are exclusively breastfed have an excellent nutritional status (Atika, 2014). Therefore, the goal of this study is to investigate at the correlation between exclusive breastfeeding and the development of nutritional status in babies aged 6 to 24 months. Age, gender, activity, weight, and body length all influence a person's dietary requirements. The parameter for measuring nutritional status commonly used in Indonesia is weight for age (Marimbi, 2010). It is because the growth and development of infants are influenced by the number of nutrients consumed. Judging from the age factor of the sample in this study, the best nutritional need for infants aged 6-24 months is breast milk. Breast milk is a hygienic food, inexpensive, easy to give, and readily available for babies. Breast milk is the main nourishment a newborn need for the first six months of his existence in order to grow into a healthy baby. Its dynamic composition and the baby's needs make breast milk the optimal nutritional intake for babies. Breast milk and plasma have the same concentration of ions, so the baby does not need additional fluids or food. Breast milk has all the elements that meet the baby's nutritional needs for about six months. Exclusive breastfeeding has a good impact on the baby's body, namely as a single food to meet all his needs, increasing the baby's immune system, as an anti-allergy, increasing intelligence and improving the relationship of affection between mother and baby (Atiqa, 2016).

According to the findings of this study, it is known that the majority of infants in this study, which amounted to $58 \%$, had received exclusive breastfeeding. And from the data on the distribution of nutritional status, it is known that $74 \%$ of respondents' babies have an average weight category. The findings of this study's chi-square analysis identified a correlation between exclusive breastfeeding and the occurrence of nutritional status in babies aged 6-24 months at the Kedungsari Health Center in Mojokerto Regency. Of $100 \%$ of respondents who were exclusively breastfed, $96.6 \%$ of respondents had normal nutritional status. The findings of 
this study support earlier research by Giri et al. (2013), which bridged the gap between exclusive breastfeeding and nutritional health in infants aged 6 to 24 months. We suggest that our findings could be more representative for correlation analysis than previous work since we used a big sample size in this study.

The findings of this investigation contradict the theory presented by Paramitha (2010), which states that exclusive breastfeeding is not always a factor that affects nutritional status, but some factors influence nutritional quality itself. These elements are strongly connected to the family's degree of education, knowledge, and abilities. The higher the degree of education, knowledge, and skills, the higher the level of family food security, the better the parenting style for children and families, and the greater the use of current resources. Family food security is also affected by food availability, food costs, family power, and nutrition and health knowledge (Waryana, 2010).

According to Adriani (2012), not always do babies with non-exclusive breastfeeding have a poorer or less nutritional status than babies with exclusive breastfeeding. Nutritional insecurity in newborns is caused by a lack of food and the substitution of bottled milk for breast milk in a way and amount that does not fulfill the needs. In addition, excess or lack of nutrient intake in infants can affect nutritional status and health status. Another factor that can affect the nutritional quality of children is genetic factors (Proverawati, 2011).

\section{CONCLUSIONS}

The majority of the babies in this research ranged in age from 6 to 24 months had been exclusively breastfed (58\%). The majority of children aged $6-24$ months in the study had normal nutritional status (74\%). There is a correlation between exclusive breastfeeding and nutritional status in children aged 6-24 months at the Kedungsari Health Center, Mojokerto Regency.

\section{ACKNOWLEDGMENT}

The researcher would like to thank the Department of Public Health, Faculty of Medicine, Wijaya Kusuma University, Surabaya

\section{REFERENCES}

Adriani, M. \& Wirjatmadi, B. 2012. Pengantar Gizi Masyarakat. Jakarta: Kencana Prenadamedia Group.

Atika, N., Susanti, R., \& Setyowati, H. 2014. Perbedaan pemberian ASI Eksklusif dan Susu Formula terhadap status gizi bayi umur 7- 
The Corelation of Exclusive Breastfeeding with Nutritional Status in Babies Age 6-24 Months... Sukma Sahadewa, Nike Salindri, Sandra Miladyna, Siti Hadijah

12 bulan di Desa Reksosari

Kec. Suruh Kab. Semarang.

Ungaran: Akademi Kebidanan Ngudi Waluyo.

Giri, M.K.W., I.W. Muliarta, N.P.D.S.

Wahyuni. 2013. Hubungan

Pemberian ASI Eksklusif dengan status gizi balita usia 6-24 bulan di kampung kajanan buleleng. Jurnal Sains dan Teknologi, 2(1):184-192 Indriyani, S. 2013. Gizi Buruk dan Pola Asuh [Internet]. Tersedia dalam: http://m.suaramerdeka.com/inde x.php/read/cetak/2013/09/24/23 7848. [Accesed 5 Januari 2015]

Kementrian Kesehatan RI. 2016. Profil Kesehatan Indonesia 2015. Jakarta. Marimbi, Hanum (2010) Tumbuh Kembang, Status Gizi \& Imunisasi Dasar Pada Balita. Yogyakarta: Nuha Offset.

Marnoto, B. W. 2010. Indonesia Menyusui:
Pemberian Susu Formula Pada

Bayi Baru Lahir. Jakarta: Badan Penerbit IDAI.

Paramitha, D.S. 2010. Hubungan Frekuensi Menyusui dan Status Gizi Ibu Menyusui Dengan Kenaikan Berat Badan Bayi Usia 1-6 Bulan Di Puskesmas Alalak Selatan Banjarmasin Utara. Skripsi. Banjarmasin: Sekolah Tinggi Ilmu Kesehatan Muhammadiyah Program Studi S1 Keperawatan.

Prasetyono, D. S. 2012. Buku Pintar ASI Eksklusif. Yogyakarta: DIVA Press. Proverawati, A dan Wati, E K. 2011. IImu Gizi untuk Perawat dan Gizi Kesehatan. Yulia Medika. Yogyakarta.

Riskesdas. 2010. Riset Kesehatan Dasar.Badan Penelitian dan Pengembangan Kesehatan Kementrian Kesehatan RI Tahun 2010. 